\title{
Philosophy of Education: Cosmism in the System of Philosophical Knowledge
}

\author{
HALYNA BEREHOVA \\ Department of Philosophy and Social-Humanitarian Disciplines, Kherson State Agrarian University, 23 Stritenska, Kherson, 73006, Ukraine \\ Email: gberegova@meta.ua
}

\begin{abstract}
In this article, the attention is concentrated exactly on cosmism and its variations, and also on its role and place in the system of philosophical knowledge which is proposed to be studied in the establishments of higher education. The questions for discussion about the role and place of cosmism in the content of higher education are put forward: Is it necessary for students to study cosmism? Should this knowledge be given in courses? How should it be given for apprehension? Philosophical knowledge is stated to be used as an instrument to form worldview orientations of the future man being able to secure the survival of civilization and mankind. Firstly, the ideas of cosmism help regard the human being as a component of the Cosmos, determine his role and place in the evolutionary processes of the Universe, discover the influence of cosmic forces upon him and the human civilization. Secondly, the ideas of cosmism in the structure of philosophical knowledge carry out humanistic and cultural functions: they complete building the world picture (as scientific, as universal) in the student's consciousness.
\end{abstract}

Keywords: philosophical knowledge, cosmism, anthropocosmism, noospherism, philosophy of education, planetary and cosmic worldview

\section{INTRODUCTION}

Global consequences of the scientific and technical progress, the exit into space make us think over the social and philosophical problem 'the man - the universe', the problem of correlation between a cosmic particle of dust of the personality possessing mind and gigantic, practically endless universe.

Nowadays, this thought turns into worries about the future of space, the planet and mankind. And this is quite normal and natural that it has found the fullest expression of different points of view of the most advanced part of the world intellectual and political elite in the last report of the Roman Club 'Come On! Capitalism, Short-termism, Population and the Destruction of the Planet' (Weizsaecker, Wijkman 2018). The report ends in determining the education of future (Sects. 3.18). It goes about the education for the stable civilization, the education as one of the main instruments of the society. We read in the text: 'The real challenge is to develop in students a capacity for problem solving, as well as critical, independent and original thinking. The education that focuses exclusively on the mind alone is no longer sufficient. The radical reorientation of educational content and pedagogics should include the transmission of knowledge acquired from the past experience ... (Weizsaecker, Wijkman 2018: 196). 
One of these philosophical and educational problems in the modern social and cultural situation is providing a new generation with successful socialization in the conditions of informational future. It demands, in its turn, to form a new, modern planetary and cosmic worldview of the personality.

What is the main feature of the 'new, modern, planetary and cosmic worldview' of the personality? - We call this worldview new, taking into account constantly changed living conditions for the mankind - constant change of the world - nature, personality, society. Such state of affairs needs qualitatively new generations able to limit consuming treatment of the planet and management in space.

The formation of the planetary and cosmic worldview is the prerogative of the relatively new social and scientific discipline - philosophy of education. This interdisciplinary theoretical branch of knowledge based on the principle of primacy of education as a determining factor of spirituality transmits the main philosophical and educational concept of three vectors: who (which person) to instruct and educate within the growing generations, how (with the help of what and in what way) it should be done and what for (with what purpose). In the author's previous work, the formation of a person in future in higher school and the pragmatic and instrumentalist concept of philosophy of education are mentioned (Berehova 2012, 2016).

A whole complex of disciplines is favourable to the formation of the planetary and cosmic worldview of the future person, and philosophy takes a special place among them. The range of the philosophical knowledge traditionally contains the triad 'nature-person-society'. Exactly in the sphere of the philosophical knowledge about nature (world, space), there are the disciplines: onthology, natural philosophy, cosmology, etc. being able to be added with cosmism, anthropocosmism and noospherism.

In this connection some questions about the role and place of cosmism in the context of higher education seem to be logic: Is it necessary to study this philosophical trend? Why should this knowledge be given at the philosophical courses? When is it more expedient to give it for understanding?

\section{COSMISM IN THE SYSTEM OF PHILOSOPHICAL KNOWLEDGE}

Nowadays, the ideas of cosmism (and those of noospherism) are getting especially important, as it becomes evident that the mankind by means of its activity lays not only reasonable grounds to continue a cosmical evolution, but also preconditions of its negative perspective. Such are the global problems 'threatening the existence of anthropology in the world' and having already convinced the mankind not only to change the style of thinking, but also the directions of social production which destroy natural environment. Otherwise, an evolutionizing biosphere can enter such state where there is no place for anthropology.

The cinema connoisseur and educator Maryna Braterska-Dron writes: 'Total development of environment, depletion of natural resources, creation of a new technogenic reality, pollution of biosphere, precessional ? increase of Earth population and other realities with no exaggeration did not only give way to doubts about the man's existence as a biological species, but created a real threat for the whole planetary system which is an important link of the whole cosmic and evolutional process' (Braterska-Dron 2004: 3).

Summarizing everything said above, we admit that a summarizing excursus to the sources of cosmism is important to determine the place and role of this direction in the system of the philosophical knowledge for a higher school. 
In the 18th century, the American thinker John Fiske (1842-1901) in his work 'Outlines of Cosmic Philosophy' tried to spread the theory of evolution to the whole cosmos (Fiske 1902). Later, the religious-philosophical and natural-scientific trends of cosmism appeared. The religious-philosophical trend was represented by the phisosophers Mykola Fedorov, Volodymyr Soloviov and others who were worried about the destiny of humanity engaged into the rhythm of endless formation of history. However, cosmism got a more precise definition in the natural-scientific studies of the famous scientists-theoreticians: Volodymyr Vernadskyi, Kostiantyn Tsiolkovskyi, the physicist Mykola Umov, the biologist Mykola Kholodnyi, the biophisicist Oleksandr Chyzhevskyi and others. It is necessary to make an accent on the natural-scientific trend of cosmism and on its brilliant representatives, as just this trend should be included into the philosophical courses of higher educational establishments to form a scientific picture of the world imagination of future professionals.

Mykola Umov (1846-1915) elaborated the principles of the anthropological worldview in physics working at Odesa University. He thought that 'the person can consider himself as a part, quickly passing link of the Universe' (Umov 1916: 215). The life origin, to his mind, is an unlikely phenomenon, but, having appeared and stated on Earth, it is being developed towards the forms which are more able to fight for existence: 'And in this direction, the mind armed with scientific knowledge appeared on Earth: this is the last bet of the alive! The last bet!' (Umov 1916: 427). By the way, the cosmos does not give? any guarantees to preserve life and its expansion: it is absolutely indifferent to the personality whose sense of existence is to preserve and confirm life on Earth.

Umov was one of the first to be against the theory of inevitable 'thermal death' of the Universe, because he thought that the latter is an endless open system for which the laws functioning in closed systems are not typical. He insisted on the phenomenon of entropy (dispersion of energy) and that of energy regeneration and concentration, so the Sun cannot get cold essentially. He expanded the law of energy preservation and transformation discovered by Mykhailo Lomonosov upon all, with no exception, the systems and upon the whole cosmos as this law 'governs the Universe life' (Umov 1916: 68). Though Mykola Umov's anthropological principle was not developed in details, his cosmological theory is penetrated with his personal world sense and worries about the destiny of the Universe and the man's life in it (Umov 1950).

Mykola Kholodnyi (1882-1953) developed the ideas of cosmism actively. The scientist thought that 'the individual, despite essential peculiarities the life environment, created by him, continues to be an integral part of the cosmos subjecting its laws' as the man is not above nature but in it (Kholodnyy 1982: 142). Kholodnyi introduced into the scientific circulation the term 'anthropocosmism', the essence of which means that 'there are the two fundamentals in the relationship between the man and nature - the aspiration not only to conquer its forces to his will, but to penetrate as deeply as possible into the mysteries of the structure and evolution of the cosmos, matter, unrelated to the possibility of using the acquired knowledge for practical goals. It is evident, only in this way it is possible to find a clue to understand the man's nature which is an organic part of the cosmos, born by it and tightly connected with it' (Kholodnyy 1982: 178). Thus, anthrocosmism changes anthrocentrism and assists elaborating new forms of social relations, deserving the individual realizing his place and role in the Cosmos.

The scientist lays a great responsibility for the future of the whole cosmos upon the individual and his mind. In his opinion, 'precisely in the individual, the living nature reached 
that degree of evolution where mind, freedom of will and moral ideals acquire ruling meaning in his life and further development. Mind gives the individual the possibility to foresee the consequences of his deeds, freedom of will - to direct them towards the formulated goals' (Kholodnyy 1982: 178). Thanks to these qualities, the personality becomes one of the consciously acting factors that makes him an immediate participant of the processes of cosmic scale and meaning.

Kostiantyn Tsiolkovskyi (1857-1935), an outstanding scientist and the founder of astronautics, foresaw an anthropological cosmic principle in his time as well. To his mind, in the course of evolution, the matter created the man not only to move towards the highest level of its development but to get to know itself with his help. The whole nature of the world formation had a purpose to create the man with unlimited abilities of his brain and mind. The nature reached it having concentrated all its great possibilities in the molecular structure of substance, for the man's brain to appear billions of years later whose impressing abilities are caused with functioning of billions of cells. One of the greatest abilities of this brain is knowledge (why, what for, etc.) - in this way the matter in the man's image is asking questions about the sense of its existence and eager to get an answer. When the man accumulates the knowledge including philosophers, writers, artists, scientists, theologists' education to know the complete verity about the world, he enters a cosmic era.

According to Tsiolkovskyi, the cosmic being of mankind goes through the four main eras: the birth era (some billions of years), the formation - the settle of the mankind in the whole cosmos (hundreds billions of years), the mankind flourishing (hundreds billions of years) and the terminal era (about some decades billions of years), when the mankind can answer 'why?' and goes from the corpuscular, material form of existence to the wavy, 'radial' form of being. Then, many billions of years after, the radial era will be changed into the corpuscular era, but of a higher level, and the same cycle will begin: nebulae, stars and planets will appear, in the course of evolution, a more modern man than in a previous cycle of knowledge. As a result, the cosmos will be very perfect.

Pierre Teilhard de Chardin (1881-1955), paleontologist and theologian, logically continued the thought about the merging of all the human minds and freedoms into the only active supermind. In his book 'The Phenomenon of the Man', he gives a specific answer to the eternal question about the sense and purpose of the man's existence: he is a complicated developed comprehensive 'microcosm', having all the potentials of the cosmos (Teilhard de Chardin 2002: 18). It means that the life and man having appeared on Earth as a result of the spontaneous origin from pre-biological organic combinations are inextricably connected with the cosmic processes of the matter complication. Earth life is a qualitatively new manifestation of this general tendency. Even though a lifeless matter seem 'dead' to us, it is only 'pre-living' and has a potential to become alive. Thus, life is cosmic in its nature because its beginning is held in the universum. (The scientist does not use the term 'universum' accidentally, he is convinced: under the layer of elementary particles of the primary matter there is a thin layer of mentality.) The human being is a jump into the evolution of Earth life, the crowning point of the uninterrupted evolutional movement; the beginning of evolution striving for the Omega point - planetary consciousness, the spiritual 'egg of the world'. The world evolution does not go in the spacious but psychical direction, it is realized not in the cosmic expansion of the mankind but in the limits of the planet.

Teilhard de Chardin pays attention to that paradoxical fact that the human being has not found his proper place in the world structure given by the modern science yet. In the science 
about the Universe (cosmology), the man and his existence are not examined. '... The human being is the most mysterious scientific object. And it's worth to admit, that in its depictions of the universum, the science has not found a place for it. Physics managed temporarily to determine the world of atom. Biology could put things in order in the life constructions. Basing on physics and biology, anthropology explains in its turn the structure of the human body and some mechanisms of its physiology. But the portrait (image) received in the unification of all these features doesn't respond the reality' (Fromm 1988: 443-481). As everything, that is got to know, is concentrated in the human being, everything is put up to the science about him: as the human being's understanding is a clue to discover mysteries of nature.

Volodymyr Vernadskyi (1863-1945), naturalist-encyclopedist and thinker, introduced at first a concept of biosphere (the totality of living organisms), then a concept of noosphere (the sphere of mind) into the scientific picture of the world. In the biospherical concept, the notion about living substance is central. The scientist regards the geochemical work of living substance as work of the united whole in the continuous connection of animals, plants and mankind. He speaks about the uninterrupted growth of the central nervous system of living organisms, its significance in the biosphere and also a specially good organization of the biosphere in itself. He states that the uninterrupted process of evolution accompanied by appearance of new species of organisms influences the whole biosphere in general: the evolution of species becomes wider and spreads all over the whole biosphere.

The noospherical concept embraces the scientist's ideas and views about the reformation of Earth space and biosphere. Analysing the anthropologic activity, he came to the conclusion about the process of biosphere transition to noosphere. Noosphere - 'the realm of human intellect' - makes 'the last state of the biosphere evolution in the geological history - the state of our days' (Vernadskiy 1988: 510).

So, philosophical ideas of cosmism found feedback in the views of further generations of thinkers forming themselves gradually in something perfect, systematically exposed world comprehension. Liubov Drotianko writes that it was 'like a peculiar answer to time challenge, marked with stormy events and upheaval in the social life and with revolutionary movements in the studies of nature, where the style of rationalism changed, when the classical style of thinking yielded the nonclassical? one' (Drotianko 2000: 186). The heterogeneity of the phenomenon of cosmism and cosmological anthropical principles is resulting from it.

At present, the notion 'cosmos' is being displaced in a way in the scientific usage with the notion 'universe', keeping at the same time historical, cultural and philosophical meanings. Some ideas of the ancient cosmology (e.g. the nature inspiration) find feedback in the circle of separate philosophers, especially supporters of hylozoistic and pantheistic ideas.

Summarizing this excursus to the sources of cosmism and its variations, one should emphasize the two positions: 1) general significance of the ideas of cosmism for the development of a philosophical thought; 2) the role and place of cosmism in the system of philosophical knowledge proposed to be studied in the higher educational establishments.

Firstly, in general, the ideas of cosmism help comprehend the human being as a component of the Cosmos, find out his role and place in the evolutionary processes of the Universe, ascertain the influence of cosmic forces on him and on the human civilization development. These ideas have generated many new hypotheses about the Universe and Earth origin, formation and development. On the wave of cosmism, for example, the laws of unequal-ponderable thermodynamics were discovered. These laws reflect nonlinear, stochaistic ?, cooperative and other peculiarities of the open, self-regulated systems which are all the components of 
the cosmic process. This led to the formation of a new interdisciplinary subject - synergetics which studies the interaction patterns of parts and the whole taking into consideration the system features mentioned above.

Secondly, the ideas of cosmism in the structure of philosophical knowledge carry out humanistic and cultural functions: they make the scientific and universal world picture in the student's consciousness perfect. Here are Teilhard de Chardin's thoughts: a) they outline the Universe, to which typically human features are introduced as a new dimension of the world; b) the ideas of cosmism convince others in the importance of such a type of the world vision, where the man is given a corresponding place in the Universe structure; c) these ideas prepare a psychological basis to form an anthropic cosmological principle giving a possibility of the whole world and man's vision, regarding the latter as one of the world essential element.

According to Oleh Bazaluk, the human being in future is harmonious: intelligent, spiritually developed, physically perfect, responsible, creative, active. Bazaluk writes: 'The meanings of the theory of education "Those who transform the Universe" upon which the theory is built, and which it generates, are much broader than the ideas of transhumanism?, philosophical posthumanism? and cosmism. They reveal the onthological cosmic nature of the man; give the possibility of the ascent from the understanding of "myself", towards the understanding of oneself as that who transforms the Universe for good of future generations' (Bazaluk 2017: 12).

\section{CONCLUSIONS}

In terms of all said above about the role and substantial filling of cosmism in the structure of philosophical knowledge proposed to students to be learned, some conclusions should be made.

1. What role does philosophy of education play in the philosophical cognition? - Philosophy of education plays a correcting role in the instruction and education of the next generations, its mission is to form a 'new, modern, planetary and cosmic worldview' of the personality in the constantly changed world. In general, philosophy of education correcting the selection of the content of knowledge is able to influence instruction and education with philosophy - to use philosophical knowledge as an instrument of instructional and educational influence.

2. Is it possible to use philosophical knowledge as the basis to form such a new, modern, planetary and cosmic worldview of the personality? - Yes, it is. Exactly philosophy and, more precisely, philosophical knowledge includes great instructional and educational possibilities as to the predicted influence upon an individual. Just the pragmatic and instrumental approach 'to education allows to use philosophical knowledge as an instrument of forming worldview landmarks of the future human being who is able to secure the civilization and mankind's survival' which was mentioned several times in some works of the author of this article (Berehova 2012, 2016).

3. How could the theories called 'cosmism' contribute to building a new, modern, planetary and cosmic worldview of the personality? - Philosophical knowledge about cosmism is necessary in this controversial process of forming a new, modern, planetary and cosmic worldview of the personality, as it makes a future specialist think about the values and sense of his/her activity and the mankind's activity in a whole, instills general humanistic values, develops ability to think by cosmic categories, gives realization about human life quality 
dependence not only of a certain country but of the whole planet. Cosmic theories are not enough means to solve modern ecological problems (especially from the point of view of 'the old anthropomorphic presupposition about an exclusive place of man in the Universe'), but they being a part of the whole system of philosophical knowledge induce greatly to build a new relationship between man and nature. Philosophy of education demonstrates this giving us the main scenarios of the mankind's ecological development: from cosmocentrism, geocentrism, anthropocentrism, technocentrism, biocentrism to ecocentrism.

4. How could this worldview of the personality contribute to solving the problems of modern Western life?

The review of the ways of solving the problem of forming worldview in the Western life (Western culture) demands a special research because, regarding the polysemy of the definition of 'worldview', this problem exists in different spheres of human comprehension and experience such as knowledge, politics, economics, religion, culture, science and aesthetics (Wikipedia alone refers to more than 400 articles about worldview) (Wiki Worldview Themes 2019). That is why this question can be touched superficially.

In the Western life (Western culture), a person's worldview formation is examined mostly in some dissertations on Psychology. So, for example, Andreas Nilsson's (University of Gothenburg, Sweden) own research addresses to Humanism and Normativism, which are the broadest and potentially most important worldview constructs in the research literature today (Nilsson 2013).

The cosmic worldview of the researchers of the Advanced Institute of Ontological Principles and New Science on the page 'NCP X-AIONS: New Cosmic Paradigm' is not ordinary. The cosmic worldview is considered to be a new ontology, new paradigm, new whole picture of the world illustrating a vital, multidimensional, endless multiworld where life is conducted with the all-round consciousness in the harmny with eternal creative principles and exact natural laws. Besides, here the cosmic worldview is based on the knowledge given by the Danish philosopher-intuitivist Martinus Thomsen (1890-1981) and his colleague Per Bruus-Jensen (The Cosmic Worldview-Martinus Cosmology 2019).

Special researches dedicated to the formation of an individual's planetary and cosmic worldview are few. Though the exploration of Shelley Richardson 'Pedagogy of Cosmic Place', where ... 'the potential role of Pedagogy of Cosmic Place in mainstream learning environments is also explored' original (Richardson 2015).

However, the problems of the planetary and cosmic worldview formation by means of philosophical knowledge with the correcting function of philosophy of education are examined actively by the members of the International Society of Philosophy and Cosmology (International Society of Philosophy and Cosmology 2019).

Received 16 March 2019 Accepted 23 January 2020

\section{References}

1. Bazaluk, O. 2017. 'The Theory of Education: Those Who Transform the Universe', Future Human Image 8: 9-13.

2. Berehova, H. 2012. Educational Potential of Philosophical Knowledge in the System of Higher Agrarian Education in Ukraine. Kherson: Ailanthus.

3. Berehova, H. 2016. 'Philosophy of Education: Pragmatism-Instrumentalism Concept of Forming the Future Human in Higher Education', Future Human Image 3(6): 31-45.

4. Braterska-Dron, M. 2004. Moral Dimension of the Philosophy of Cosmism. Abstract of doctoral theses. Kyiv: H. S. Skovoroda Institute of Philosophy NAS of Ukraine. 
5. Drotianko, L. 2000. The Ukrainian Context of the Cosmic Philosophy: Universal Measurements of Ukrainian Culture. Odessa: Print, 184-186.

6. Fiske, J. 1902. Outlines of Cosmic Philosophy: Based on the Doctrine of Evolution; with Criticisms on the Positive Philosophy. Boston and New York: Houghton Mifflin and Company.

7. Fromm, E. 1988. Ways From a Sick Society. Man's Problem in the Western Philosophy. Translations. Moscow: Progress.

8. International Society of Philosophy and Cosmology. Official site available at: https://www.bazaluk.com/ about-International-Society-of-Philosophy-and-Cosmology.html (accessed 31.10.2019).

9. Kholodnyy, N. 1982. Selected Works. Kiev: Naukova dumka.

10. Nilsson, A. 2013. The Psychology of Worldviews: Toward a Non-Reductive Science of Personality. Lund University.

11. Richardson, Sh. 2015. Pedagogy of Cosmic Place: Discovering Universality with Montessori \& the Natural World. Markham: Eddy Press.

12. Teilhard de Chardin, P. 2002. The Phenomenon of the Man. Moscow: Izdatelstvo AST.

13. The Cosmic Worldview - Martinus Cosmology. Available at: https://newcosmicparadigm.org/the-ontology-of-the-cosmic-worldview-introduction-eng/ (accessed 31.10.2019).

14. Umov, N. 1916. Collection of Works. Vol. 3. Speeches and Articles of General Content. Moscow: Typolytography Kushnerev and Co.

15. Umov, N. 1950. Selected Works. Moscow-Leningrad: State Publishing House of Technical and Theoretical Literature.

16. Vernadskiy, V. 1988. Philosophical Thoughts of a Naturalist. Moscow: Nauka.

17. Weizsaecker, E.; Wijkman, A. 2018. Come On! Capitalism, Short-Termism, Population and the Destruction of the Planet. New York: Springer.

18. Wiki Worldview Themes: Structure for Characterizing and Analyzing Worldviews. Available at: https://projectworldview.org//wikiworldviewthemes.htm (accessed 31.10.2019).

\title{
HALYNA BEREHOVA
}

\section{Švietimo filosofija: kosmizmas filosofinių žinių sistemoje}

\begin{abstract}
Santrauka
Straipsnyje sutelkiamas dèmesys ị kosmizmą ir jo variacijas, taip pat ị filosofinių žinių aktualumą, kurias siūloma studijuoti aukštojo mokslo programose. Keliami ir diskutuojami šie klausimai: ar studentams būtina studijuoti kosmizmą; ar šios žinios turi būti pateiktos atskiru kursu; kaip jis turi būti suvokiamas? Filosofinès žinios, plètojančios civilizacijos ir žmonijos išlikimo temas, skirtos kaip instrumentas formuoti pasaulevaizdinę ateities žmogaus orientaciją. Pirma, kosmizmo idèjos padeda pažvelgti į žmogaus būtį kaip ị kosmoso komponentą, apibrèžia jos vaidmenị ir vietą Visatos evoliucijos procese, atskleidžia kosminių jẻgų poveikị jai ir žmonijos civilizacijai. Antra, kosmizmo idèjos filosofijos žinių diskurse atlieka humanistinę ir kultūrinę funkcijas: jos padeda suformuoti pasaulèvaizdị studentų sąmonèje.
\end{abstract}

Raktažodžiai: filosofijos žinios, kosmizmas, antropocentrizmas, neosferizmas, ugdymo filosofija, planetinis ir kosminis pasaulevaizdis 